\title{
Impaired coronary flow reserve immediately after coronary angioplasty in patients with acute myocardial infarction
}

\author{
Masaharu Ishihara, Hiakaru Sato, Hironobu Tateishi, Takuji Kawagoe, \\ Mitsuisa Yoshimura, Yuji Muraoka
}

\begin{abstract}
Objective-To examine coronary flow reserve immediately after emergency coronary angioplasty in patients with acute myocardial infarction.

Design-A 3 F coronary Doppler catheter was used to measure coronary blood flow velocity in the infarct artery and in the non-infarct artery. Maximal hyperaemia was produced by $10 \mathrm{mg}$ of intracoronary papaverine and coronary flow reserve was calculated.
\end{abstract}

Patients-11 patients with acute myocardial infarction undergoing both emergency coronary angioplasty $(4 \cdot 7$ (3.6) h after the onset of chest pain (mean (SD))) and at follow up catheterisation 16 (4) days after angioplasty.

Setting-Hiroshima City Hospital.

Results-There was no stenosis of $\geqslant 50 \%$ in the coronary artery of interest. Immediately after coronary angioplasty the mean (1 SD) coronary flow reserve of the infarct artery was significantly less than that of the non-infarct artery $(1.4$ $(0.4) v 2.8(0.8), p<0.001)$. At follow up catheterisation the coronary flow reserve of the infarct artery increased almost to the value of the non-infarct artery $(2.8$ $(1 \cdot 2) v 3 \cdot 1(0 \cdot 8) \mathrm{p}=\mathrm{NS})$.

Conclusion-The coronary flow reserve in the infarct region was severely impaired immediately after reperfusion, even with a widely patent infarct artery. This could restrict the beneficial effects of reperfusion therapy, especially when there is a severe residual stenosis.

(Br Heart J 1993;69:288-292)

Coronary reperfusion during early hours after the onset of acute myocardial infarction can salvage jeopardised myocardium, improve ventricular function, and enhance survival. ${ }^{12}$ Though emergency coronary angioplasty for acute myocardial infarction achieves recanalisation of the infarct artery by achieving minimal residual stenosis, ${ }^{3}$ previous animal studies have shown that coronary flow reserve in the infarct region is much reduced during reperfusion after coronary artery occlusion ${ }^{45}$ and it may not be possible to increase coronary blood flow sufficiently to revitalise potentially viable myocardial tissue.

With the coronary Doppler catheter it is possible to measure coronary blood flow velocity in the basal state and after a vasodilator stimulus and calculate the coronary flow reserve in a target artery of the human heart. $^{67}$ Using this technique we assessed coronary flow reserve immediately after emergency coronary angioplasty in patients with acute myocardial infarction.

\section{Patients and methods}

PATIENTS

We examined coronary flow reserve in 11 patients (10 men and a woman, 53 (14) years (mean (SD))) with acute myocardial infarction undergoing both emergency coronary angioplasty and follow up cardiac catheterisation.

Chest pain consistent with ongoing myocardial ischaemia that persisted for $>30 \mathrm{~min}$ utes and caused at least $1 \mathrm{~mm}$ ST elevation in at least two leads was diagnosed as acute myocardial infarction. Each patient underwent emergency cardiac catheterisation within 12 hours of the onset of symptom $(4 \cdot 7(3.6) \mathrm{h})$. Creatine kinase was measured every three hours after hospital admission and peak serum creatine kinase concentration was more than twice of the upper limit of the normal range (3127 (1330) IU/1).

Informed consent was obtained from each patient and their next of kin for the coronary Doppler measurement and intracoronary papaverine injection. This study was approved by the hospital ethics committee.

\section{CARDIAC CATHETERISATION AND CORONARY} ANGIOPLASTY

In all patients the femoral approach was used for ventriculography and coronary angiography. After vascular access was obtained 5000 units of heparin was administered. Left ventriculography was performed in the $30^{\circ}$ right anterior oblique projection and the left ventricular ejection fraction was calculated by the area-length method. ${ }^{8}$ The left ventricular end diastolic pressure was measured via a pigtail catheter before ventriculography. Coronary angiography was performed in multiple projections. At initial angiography each patient had an occluded infarct artery (seven left anterior descending artery and four left circumflex artery) and no other coronary artery disease, which was defined as $50 \%$ narrowing of the luminal diameter of a major vessel or a major branch. Five patients had collateral circulation supplying the infarct artery. After initial angiography, $0.5 \mathrm{mg}$ of glyceryl trin-
Hiroshima City Hospital,

7-33 Moto-machi, Naka-ku Hiroshima, 730 Japan.

Accepted for publication 13 April 1992 
itrate was infused into the left coronary ostium and tissue plasminogen activator was infused intravenously for over 60 minutes. After thrombolysis, an additional 5000 units of heparin was administered and coronary angioplasty was performed in a conventional manner, with a balloon with the same diameter as adjacent, non-diseased arterial segments. After coronary angioplasty, there was no significant residual stenosis $(21(13) \%)$. The percentage diameter stenosis was measured with handheld callipers. ${ }^{9}$

\section{MEASUREMENTS OF CORONARY BLOOD FLOW VELOCITY (FIG 1)}

After the final balloon inflation 5000 units of heparin was administrated and the coronary Doppler study was performed. The coronary blood flow velocity was measured with a $3 \mathrm{~F}$ coronary Doppler catheter (Millar Mikro-Tip $20 \mathrm{MHz}$ Doppler catheter, model DC-101) in the left anterior descending artery and circumflex artery. The Doppler catheter was placed through an $8 \mathrm{~F}$ angioplasty guiding catheter over a 0.014 inch guide wire placed distally in the selected artery. ${ }^{7}$ Doppler flow measurements were made first in the non-infarct artery. After stable signals of baseline coronary blood flow velocity were obtained, $10 \mathrm{mg}$ of papaverine hydrochloride ( $1 \mathrm{mg} / \mathrm{ml} \quad 0.9 \%$ saline) was injected through the guiding catheter into the left coronary ostium and a continuous recording was obtained throughout the peak hyperaemic response for at least five minutes. ${ }^{10}$ After the coronary blood flow velocity had returned to the baseline value the Doppler catheter was advanced into the infarct artery and positioned immediately proximal to the infarct lesion. Again the baseline and hyperaemic coronary blood flow velocities were measured in the infarct artery.
Mean and phasic signals of coronary blood flow velocity, arterial pressure obtained via the guiding catheter, and the electrocardiogram were continuously recorded on a multichannel direct-writing recorder.

FOLLOW UP CARDIAC CATHETERISATION AND MEASUREMENTS OF CORONARY BLOOD FLOW VELOCITY

Catheterisation was performed 10 to 22 days (16 (4) days) after emergency coronary angioplasty. All vasodilators were stopped at least 24 hours before the catheterisation. Left ventriculography, coronary angiography, and measurements of baseline and hyperaemic coronary blood flow velocity were obtained as before. No patient had developed reocclusion of the infarct artery and residual stenosis was $<50 \%(22(12) \%)$.

CORONARY FLOW RESERVE ANALYSIS

Coronary flow reserve was calculated as the quotient of mean hyperaemic coronary blood flow velocity and mean baseline coronary blood flow velocity.

\section{STATISTICAL ANALYSIS}

Statistical analysis was performed with the paired $t$ test. A p value of $<0.05$ was used to define statistical significance. All group data were shown as mean (1 SD).

\section{Results}

HAEMODYNAMIC DATA

The table shows the systemic haemodynamic data. Heart rate was significantly higher immediately after coronary angioplasty than at the subsequent catheter study. There was no significant difference in other haemodynamic factors between the two study periods.
A

Non-infarct artery $\quad$ Papaverine $10 \mathrm{mg}$

ECG
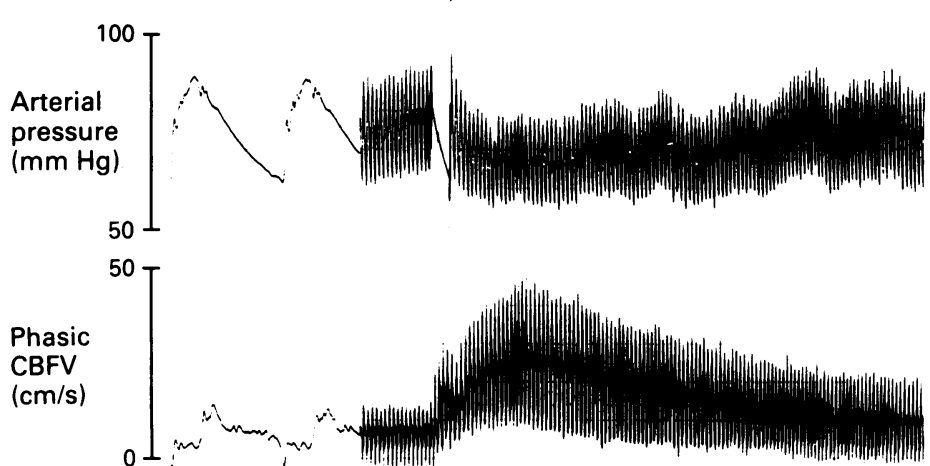

CFR $=3.9$

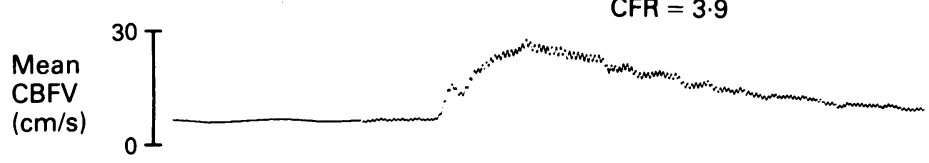

Infarct artery Papaverine $10 \mathrm{mg}$
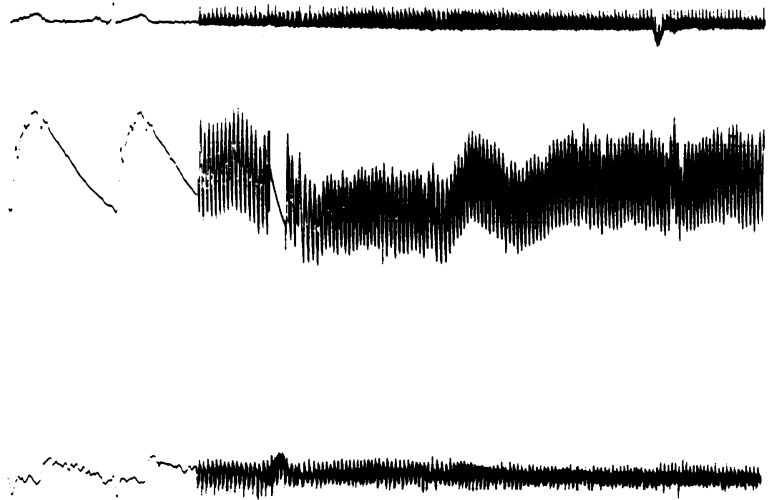

$\mathrm{CFR}=1 \cdot 3$

Figure 1 Typical recordings obtained immediately after coronary angioplasty. (A) After an intracoronary injection of papaverine (10 mg) mean coronary blood flow velocity $(C B F V)$ in the non-infarct artery rose to 3.9 times the resting velocity. (B) Intracoronary papaverine (10 mg) increased mean coronary blood flow velocity in the infarct artery by only $30 \%$. The coronary flow reserve (CFR) of the infarct artery was $1 \cdot 3$. ECG, electrocardiogram. 
Table Haemodynamic data (mean (ISD) immediately after coronary angioplasty and at follow up catheterisation

\begin{tabular}{|c|c|c|c|c|c|c|}
\hline & \multicolumn{2}{|c|}{$M A P(m m ~ H g)$} & \multicolumn{2}{|c|}{$H R$ (bpm) } & \multirow{2}{*}{$\begin{array}{l}L V E D P \\
(m m \mathrm{Hg})\end{array}$} & \multirow{2}{*}{$\begin{array}{l}\text { LVEF } \\
(\%)\end{array}$} \\
\hline & $N I A$ & $I A$ & $N I A$ & $I A$ & & \\
\hline $\begin{array}{l}\text { Immediately after coronary angioplasty } \\
\text { At follow up }\end{array}$ & $\begin{array}{l}95(10) \\
90(14)\end{array}$ & $\begin{array}{l}93(10) \\
91(15)\end{array}$ & $\begin{array}{l}75(14) \\
69(10)\end{array}$ & $\begin{array}{l}78(13) \\
71(10)^{\star}\end{array}$ & $\begin{array}{l}23(5) \\
21(5)\end{array}$ & $\begin{array}{l}50(14) \\
52(11)\end{array}$ \\
\hline
\end{tabular}

HR, heart rate; IA, infarct artery; LVEDP, left ventricular end diastolic pressure; LVEF, left ventricular ejection fraction; MAP, mean arterial pressure; NIA, non-infarct artery.

${ }^{\star} p=0.046$ versus immediately after coronary angioplasty.

Additionally, mean arterial pressure and heart rate were similar immediately before Doppler measurements in the infarct artery and the non-infarct artery.

\section{CORONARY BLOOD FLOW VELOCITY AND CORONARY FLOW RESERVE}

Intracoronary papaverine given immediately after coronary angioplasty caused a significant but small increase in mean coronary blood flow velocity of the infarct artery (from $15.6(11.5)$ to $20.6(13.5) \mathrm{cm} / \mathrm{s}, \mathrm{p}=0.016)$. The increase in mean coronary blood flow velocity was more pronounced in the non-infarct artery (from 8.2 $(5 \cdot 5)$ to $19.4(8 \cdot 1) \mathrm{cm} / \mathrm{s}, \mathrm{p}<0.001)$. The coronary flow reserve of the infarct artery was significantly less than that of the non-infarct artery $(1.4(0.4)$ v $2.8(0.8), \mathrm{p}<0.001)$.

At the subsequent catheter study intracoronary papaverine significantly increased mean coronary blood flow velocity in both the infarct

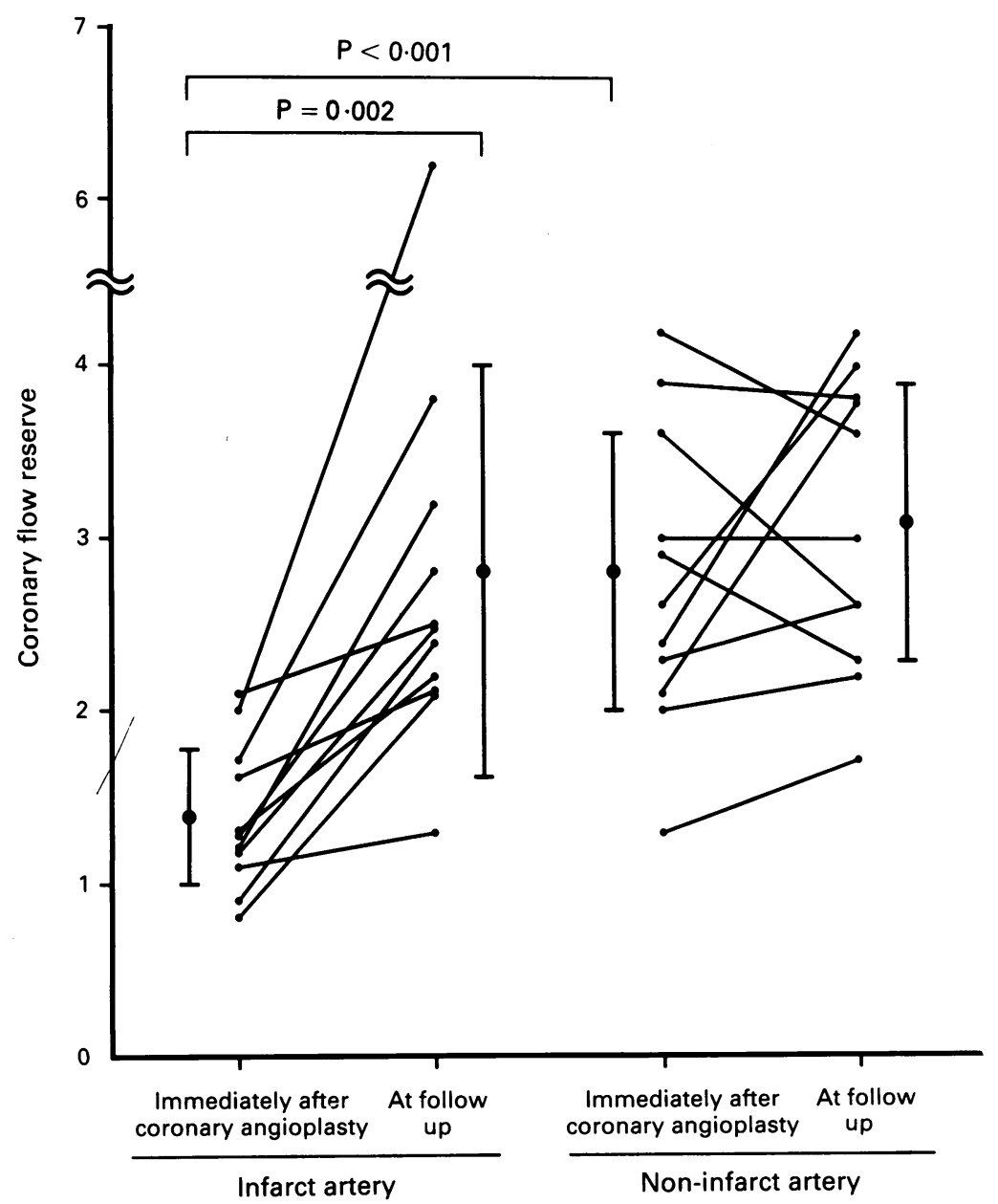

Figure 2 Coronary flow reserve shown for each patient immediately after coronary angioplasty and at the follow up catheterisation study. artery (from $11.3(4.9)$ to $29.4(10.9) \mathrm{cm} / \mathrm{s}$, $\mathrm{p}<0.001$ ) and the non-infarct artery (from $6.9(3.7)$ to $19.1(6.9) \mathrm{cm} / \mathrm{s}, \mathrm{p}<0.001)$. The coronary flow reserve of the infarct artery was similar to that of the non-infarct artery $(2 \cdot 8$ $(1 \cdot 2)$ v $3 \cdot 1(0 \cdot 8))$.

Figure 2 shows changes in coronary flow reserve in individual patients between the two study periods. The coronary flow reserve of the infarct artery increased from $1.4(0.4)$ immediately after coronary angioplasty to $2 \cdot 8$ $(1 \cdot 2)$ at the subsequent catheter study $(\mathrm{p}=0.002)$. In contrast, the coronary flow reserve of the non-infarct artery was unchanged.

\section{Discussion}

We examined coronary flow reserve immediately after coronary angioplasty in patients with acute myocardial infarction. We found that immediately after coronary angioplasty, coronary flow reserve in the distribution of a widely patent infarct artery was severely impaired and that a few weeks later it had increased to that of the non-infarct artery.

\section{HAEMODYNAMIC FACTORS}

In the current study, heart rate was significantly higher immediately after coronary angioplasty than 10-22 days later. Increases of heart rate augment coronary blood flow and it was possible that such haemodynamic factors could have influenced the measured coronary flow reserve. ${ }^{11}$ Indeed, in the current study, the mean baseline coronary blood flow velocity of both the infarct artery and the non-infarct artery was slightly higher immediately after coronary angioplasty than 10-22 days later. This is why we designed this study so that the non-infarct artery could be used as an internal control.

\section{PREVIOUS STUDIES}

Coronary haemodynamic indices during reperfusion have been extensively investigated in animal models of a coronary occlusion followed by reperfusion. ${ }^{45}$ Bloor and White ${ }^{4}$ showed that hyperaemic coronary flow in the infarct region was significantly decreased after two hours of reperfusion and gradually returned to almost the pre-occlusion control values during 96 hours of reperfusion. Parker et $a l^{5}$ showed that during 15 minutes of reperfusion coronary blood flow in the infarct region in dogs was unchanged from that in the non-infarct region, and minimal coronary vascular resistance, calculated from arterial pressure and hyperaemic coronary blood flow, rose. They also reported 
that the responsiveness of the reperfused coronary vasculature to vasodilator agents, including intracoronary papaverine, was lower than that in the normal coronary vasculature. ${ }^{12}$ Our results in human subjects confirm these experimental reports.

POSSIBLE MECHANISMS OF IMPAIRED CORONARY FLOW RESERVE IMMEDIATELY AFTER EMERGENCY CORONARY ANGIOPLASTY FOR ACUTE

\section{MYOCARDIAL INFARCTION}

The decreased coronary flow reserve of the infarct artery immediately after coronary angioplasty indicates an increase in the passive resistance in the reperfused vascular bed. The increased passive vascular resistance could be attributed to changes in the adjacent myocardium that tend to increase the extravascular pressure. The acute development of intracellular and interstitial oedema in the reperfused region has been described and this oedema could increase extravascular pressure and limit coronary blood flow. ${ }^{13} 14$

Also the increase in passive vascular resistance could result from occlusion of the microcirculation. It has been shown that flow may not return to all portions of the previously ischaemic tissue after a coronary occlusion is opened. This condition has been termed the "no-reflow" phenomenon. ${ }^{15}$ The no-reflow phenomenon could reduce the extent of the coronary vascular bed, and so decrease the coronary flow reserve. The pathogenesis of the no-reflow phenomenon is not well understood. Proposed mechanisms include direct ischaemic microvascular injury with endothelial cell swelling, ${ }^{16}$ increased vasomotor tone, ${ }^{17}$ and microvascular obstruction by leucocyte plugging $^{18}$ or thrombi. ${ }^{19}$

In addition, augmented baseline coronary blood flow with resetting of autoregulatory mechanisms after coronary angioplasty could account for an impaired coronary flow reserve. However, it was unlikely to be a main reason why coronary flow reserve of the infarct artery was severely impaired because there was no significant difference in baseline mean coronary blood flow velocity of the infarct artery between the two study periods.

\section{STUDY LIMITATIONS}

Because the $3 \mathrm{~F}$ coronary Doppler catheter measures blood flow velocity rather than blood flow, changes in the vascular cross sectional area at the site of the catheter could alter the relation between blood flow and flow velocity. ${ }^{20}$ It was shown, however, that papaverine did not alter coronary diameter in vessels previously treated with glyceryl trinitrate. ${ }^{10}$ Another limitation of this catheter is that it measures only relative blood flow velocity-that is, only changes in coronary blood flow velocity.

Because we always measured coronary blood flow velocity in the non-infarct artery first, the differences between vessels might have been affected by the injection of two doses of papaverine into the infarct artery. Wilson and White showed that the hyperaemic period produced by intracoronary papaverine was sufficiently short lived to allow multiple measurements of coronary flow reserve within a short interval. ${ }^{10}$ In our study the intervals between the first and the second intracoronary papaverine injection were long enough for coronary blood flow velocity to return to baseline level. Moreover, the mean arterial pressure and heart rate immediately before the Doppler flow measurement of the infarct artery were similar to those of the non-infarct artery.

Because we studied a small group the measured coronary flow reserve could have been influenced by the left ventricular ejection fraction, peak creatine kinase concentration, time to reperfusion, or presence of collateral circulation.

\section{CLINICAL IMPLICATIONS}

The fact that acute myocardial infarction results in an impaired coronary flow reserve in the distribution of a widely patent infarct artery implies that even after successful reperfusion it may not be possible to increase coronary blood flow sufficiently to revitalise potentially viable myocardial tissue. ${ }^{5}$ This may restrict the beneficial effects of reperfusion therapy, especially if a stenosis is severe. ${ }^{21}$ In addition during reperfusion, coronary vasodilatation may not increase coronary blood flow in the infarct region and this may cause redistribution of coronary blood flow from the infarct artery to the non-infarct artery. ${ }^{22}$ Whether this impaired coronary flow reserve during reperfusion can be counteracted by treatment and whether this would result in less myocardial damage remains to be investigated.

1 Sheehan FH, Doerr R, Schmit WG, Bolson EL, Uebis R, Essen R, Effert S, Dodge HT. Early recovery of left ventricular function after thrombolytic therapy for acute myocardial infarction: An important determinant of survival. J Am Coll Cardiol 1988;12:289-300.

2 Lee L, Bates ER, Pitt B, Walton JA, Laufer N, O'Neil WW. Percutaneous transluminal coronary angioplasty improves survival in acute myocardial infarction complicated by cardiogenic shock. Circulation 1988;78:1345-51.

3 O'Neill W, Timmis GC, Bourdillon PD, Lai P, Ganghadarhan V, Walton J, Ramos R, Laufer N, Gordon S, Schrok A, Pitt B. A prospective randomized clinical trial of intracoronary streptokinase versus coronary angioplasty for acute myocardial infarction. N Engl J Med 1986; for acute

4 Bloor CM, White FC. Coronary artery reperfusion: Effects of occlusion duration on reactive hyperemia responses. Basic Res Cardiol 1975;70:148-58.

5 Parker PE, Bashour HA, Downey HF, Kechejian SJ, Williams AG. Coronary hemodynamics during reperfusion following acute coronary ligation in dogs. Am Heart $J$ 1975;90:593-9.

6 Wilson BF, Laughlin DE, Ackell PH, Chilian WM, Holida MD, Hartley CJ, Armstrong ML, Marcus ML, White CW. Transluminal, subselective measurement of coronary artery blood flow velocity and vasodilator reserve in man. Circulation 1985;72:82-92.

7 Sibley DH, Millar HD, Hartley CJ, Whitlow PL. Subselective measurement of coronary blood flow velocity using a steerable Doppler catheter. J Am Coll Cardiol 1986;8:1332-40.

8 Dodge HT, Sandler H, Ballew DW, Lord JD Jr. The use of biplane angiocardiography for the measurement of the left ventricular volume in man. Am Heart J 1960;60:762-76.

9 Ishihara $M$, Sato $H$, Tateishi $H$, Uchida T, Dote $K$. Intraaortic balloon pumping as the post-angioplasty strategy in acute myocardial infarction. Am Heart 991;122:385-9.

10 Wilson RT, White CW. Intracoronary papaverine: An ideal coronary vasodilator for studies of the coronary circulaion in conscious humans. Circulation 1986;73:444-51.

11 McGinn $A L$, White $C W$, Wilson $R F$. Interstudy variability of coronary flow reserve: Influence of heart rate, arterial pressure, and ventricular preload. Circulation 1990; 81:1319-30.

12 Parker PE, Bashour FA, Downey HF, Boutros IS. Coronary reperfusion: Effects of vasodilators (papaverine and adenosine). Am Heart J 1977;93:66-72.

13 Powers ER, DiBona DR, Powell WJ. Myocardial cell 
volume and coronary resistance during diminished coronary perfusion. Am J Physiol 1984;247:467-77.

14 Humphrey SM, Thomson RW, Gavin JB. The effect of an isovolemic left ventricle on the coronary vascular competence during reflow after global ischemia in the rat heart. Circ Res 1981;49:784-91.

15 Kloner RA, Gantone CE, Jennings RB. The "no-reflow" phenomenon after temporary coronary occlusion in the phenomenon after temporary coron
dog. J Clin Invest 1974;54:1496-508.

16 Armiger LC, Gavin JB. Changes in the microvasculature of ischemic and infarcted myocardium. Lab Invest 1975; 33:51-6.

17 Hellstrom HR. The injury-spasm (ischemia-induced hemostatic vasoconstrictive) and vascular autoregulatory hypothesis of ischemic disease: Resistance vessel-spasm hypothesis of ischemic disease. Am J Cardiol 1982; 49:802-10.

18 Engler RE, Schmid-Schonheim GW, Pavelee RS. Leuko- cyte capillary plugging in myocardial ischemia and reperfusion in the dog. Am J Pathol 1983;111:98-111.

19 Folts JD, Crowell EB Jr, Rowe GG. Platelet aggregation in partially obstructed vessels and its elimination with aspirin. Circulation 1976;54:365-370.

20 Zijstra F, Ommeren J, Reiber JHC, Serruys PW. Does the qualitative assessment of coronary artery dimensions predict the physiologic significance of a coronary stenosis? pirculation 1987;75:1154-61.

21 Gould KL.Pressure-flow characteristics of coronary stenosis in unsedated dogs at rest and during coronary vasoin unsedated dogs at rest and

22 Picano E, Somonetti I, Masisi M, Marzilli M, Lattanzi F Distante A, DeNes M, L'Abbate A. Transient myocardia dysfunction during pharmacologic vasodilation as an index of reduced coronary reserve: A coronary hemodynamic and echocardiographic study. J Am Coll Cardio 1986;8:84-90. 